\title{
Notes on a Fishing Voyage to the Barents Sea in August, 1907.
}

\author{
By \\ George T. Atkinson, \\ Assistant at the Lowestoft Laboratory. \\ With Plate IV and three figures in the Text.
}

\begin{tabular}{l}
\multicolumn{9}{c}{ CONTENTS. } \\
$\begin{array}{l}\text { Introductory } \\
\text { The Plaice }\end{array}$ \\
Methods of obtaining and measuring samples \\
Composition of the catch \\
Maturity Examination
\end{tabular}

Chiefly with the object of obtaining material from which comparisons of an intact plaice population with that at present existing in the North Sea might be made, I undertook, in August, 1907, a voyage in a commercial steam trawler to the new fishing grounds in the "White Sea."*

As this area was only exploited commercially by trawlers for the first time in 1905, an exceptional opportunity was afforded for the study of an accumulated stock of plaice unaffected by the influence of man.

To Mr. F. O. Hellyer, who kindly arranged the voyage for me in the s.s. Roman, of the Imperial Steam Fishing Company, Hull, and to Captain W. Leighton, through whose co-operation I was enabled to measure and examine over four thousand plaice, my heartiest thanks

* Generally so mis-named. Very little trawling has taken place within the White Sea proper, nor has it proved profitable.

NEW SERIES.-VOL. VIII. NO. 2. MAY, 1908. 
are due. I am also indebted to my friend, Mr. A. E. Jones, who accompanied me and recorded the various measurements. During the collation of my material and the preparation of this memoir, I have received much valuable assistance and advice from my colleagues at Lowestoft, particularly from Drs. Wallace, Garstang, and Allen.

Owing to the keen struggle to make and keep the "White Sea" fishing a commercial success, it was naturally stipulated that the actual position of the fishing grounds should not be revealed. This from the immediate scientific point of view is immaterial, nor was it the object of the investigation.

Depths, however, are of importance in the distribution of plaice, and their insertion entails no breach of trust, as the latest Admiralty charts afford no clue to the position of the fishing bank visited. Doubtless in the course of time the fishing in the area will be generally understood, but by that time the pioneer fishermen of Hull will have reaped the rich reward of their discoveries, and the knowledge gained will continue to stand them in good stead.

I propose here to deal with the notes made on the various fishes met with during the voyage, but before doing so will recall briefly the general conditions which are found throughout the year in the Barents Sea as far as they are at present known.*

The sea is at its coldest in June. From this time an inflow of Atlantic water commences, and continues till November, bestowing a considerable increase of temperature on the whole area. After November the influence of the Arctic water gradually predominates. It has been pointed out by Knipowitsch that the fisheries of the Barents Sea are dependent on this annual flood of warm Atlantic water.

The coming of the most important fishes with this flood, and their subsequent departure when Arctic conditions again prevail, have been studied by the Russian investigators by means of fishing experiments. By these means it has been found that quantities of fish ean be obtained in the neighbourhood of the different branches of the North Cape Current at the times when there is no fishery worthy of mention on the usual fishing grounds along the Murman coast. To cite one example $\dagger$ : from May 15-17th, 1898, quantities of haddock, catfish, - halibut, black halibut, cod, Norway haddocks, tusk, and other fish were

* L. Brertruss. Ozeanographische Studien über das Barents Meer. Petermanns Mitteilungen, II, 1904.

N. KNIPowiтsch. Expedition für wissenschaftlich-praktische Untersuchungen an der Murman-Küste, I. Cf. Rapports et Procès-verbaux. Appendix A, Vol. iii, 1905.

† N. KNipowitsch. Expedition für wissenschaftlich-praktische Untersuchungen an der Murman-Küste, I, p. 594. 
caught by means of long-lines in Lat. $71^{\circ} 14^{\prime}$ N., Long. $32^{\circ} 46^{\prime}$ E., a position in the southernmost branch of the constant North Cape Current.

At this time the fishing on the Murman coast was of no importance, and the conviction of the fishermen was that no fish would be found out in the open sea.

Knipowitsch records that in March and April the Murman coast is very deficient in fish, though quantities can be met with as a rule more to the west (north of Finmark, etc.). Then the eastward migration commences, the chief shoals still being found in the neighbourhood of the well-marked warm stream. As summer approaches, they draw near the coast, and the population of the open sea decreases.

Late in summer the fish still press on to the east, towards the neighbourhood of Cape Kanin. Late in autumn the return migration from the coast commences, though many fish can remain till midwinter* off the Murman coast.

Marked differences have been observed in the fauna as the bottom temperature rises above the freezing point; it is very rare to find the valuable food-fishes present in water with a temperature below freezing point. Bearing this in mind, it is probable that the use of a satisfactory deep sea thermometer would greatly assist the efforts of our own fishermen in these regions. As they first work in this sea in June and July, $\dagger$ when the influence of the Atlantic flood is commencing to extend, a thermometer might prove as useful a guide as the lead. Though it cannot be claimed that such an instrument would show where fish are to be caught, futile trawling in the unproductive, ice-cold Arctic water, which undoubtedly has taken place, might be avoided.

By means of a simple reversing thermometer of his own design, to be worked on the ordinary leadline, kindly supplied me by Mr. D. J. Matthews, of the Plymouth Laboratory, I was able to determine on several occasions that the bottom temperature on the bank where the plaice were chiefly taken was $34^{\circ} \mathrm{F}$., or two degrees above freezing point. The surface temperature at the the same times varied from $45^{\circ}-48^{\circ}$ F. In similar depths (34-36 fathoms) in the North Sea the difference in top and bottom temperatures would only be slight.

An English trawler in June, working in suitable depths some distance to the eastward of the fishing ground now under consideration, found an almost entire absence of plaice, and the icy coldness of

* The winter in respect of the land, not sea.-G. T. A.

+ The tendency has been to make an earlier start each year. In 1907 the first trawler left Hull on May 1st. 
the water was remarked on; the region had then eventually to be abandoned, and the fishing voyage concluded at Iceland. In my notes on the plaice the influence of temperature on the movements of this species in other regions will be further indicated.

\section{The Plaice (Pleuronectes platessa).}

This was by far the most abundant species met with, and is of course the special object of the trawlers' exploitation of the region.

Throughout the greater part of this voyage on the Roman, samples of the catch were measured and examined.

\section{Methods of Obtaining and Measuring Samples.}

The method of obtaining and working through the samples was as follows: As the contents of the trawl lay upon the deck, the crew proceeded to gut the plaice and throw them one by one into the "pound" on the side of the deck opposite to which the trawl had been hauled, where they were eventually washed before being put below.

Thus, by getting one or more of the men to put their gutted fish as they picked them unselected from the deck into baskets, and by taking as many baskets as it was possible to dispose of without interfering with the regular routine of the ship, good samples could be obtained.

The gutting process consists of making an incision into the body cavity, through which the viscera, with the exception of the reproductive organs, are extracted. Thus it was comparatively easy to make an examination of the maturity of each individual fish.

The international method of measurement was adopted (e.g. 39-39.9 $\mathrm{cm}$., recorded as $39 \mathrm{~cm}$.), and the operation was carried out on a portable measuring board, on the open deck in fine weather and under the "whaleback," or roofed-in bow deck, when it was rough.

On six occasions the whole catch of plaice was measured and examined. The close agreement of the average sizes (p. 76) then obtained, with those of smaller samples at other stations in the vicinity, confirms the confidence in the value of the smaller samples.

As each measurement was made and recorded the sex of the fish was noted, together with the maturity. From these records (Table I) it will be seen that the lengths of the smallest mature fishes were 24 and $35 \mathrm{~cm}$. for male and female respectively, and the corresponding largest immature 41 and $45 \mathrm{~cm}$. The average size of the mature males is $40.9 \mathrm{~cm}$., and of the mature females $48.3 \mathrm{~cm}$.

The lengths of 113 fish (65 0,48 \%) have been excluded from all consideration, as in each of these cases the tail had been more or less 
damaged, sometimes half, and even the whole, of it being missing, and the record was only kept to show the great frequency with which this damaged condition occurred. I am strongly inclined to agree vith the fishermen, who noticed this feature in the previous year, and to attribute it to the depredations of the Greenland shark (Laemargus microcephalus), which without a doubt includes the plaice in its diet (see p. 97). If this is the case, the fact that nearly $2 \frac{1}{2}$ per cent of the fish in my samples were in this condition is significant, and shows that

TABLE I.-Showing the actual length frequencies of plaice measured on board the s.s. "Roman" in the Barents Sea, August, 1907 ; classified according to maturity:-

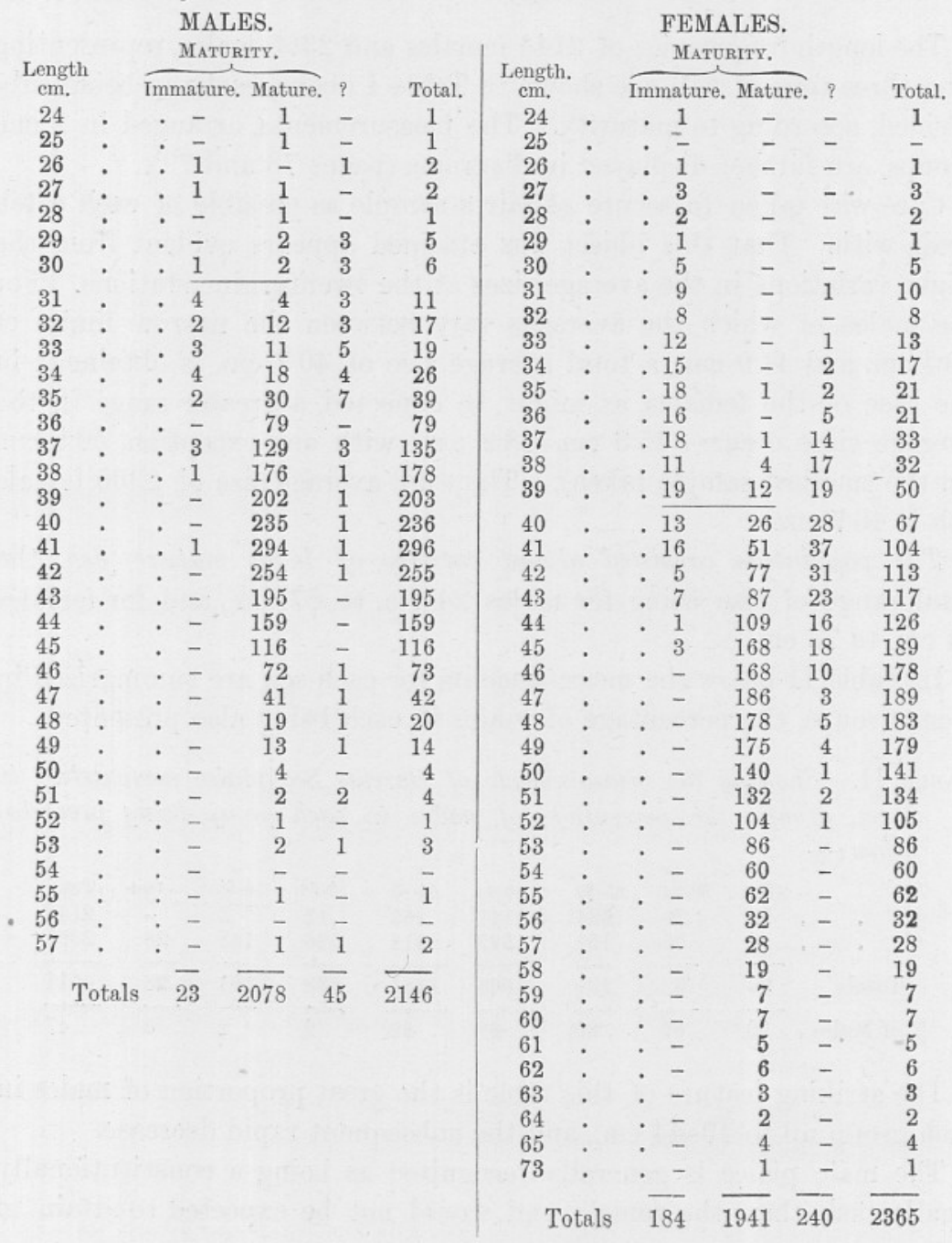


in this region at least the plaice lives in the presence of a serious natural enemy (or enemies, for though the food of the seals in the Barents Sea has not yet been sufficiently studied, the possibility of their preying upon plaice is by no means precluded).

It may perhaps seem possible that, owing to the novelty of this phenomenon, the fishermen would be inclined specially to select these damaged fish for my benefit, thus exaggerating their occurrence. I am confident that this is not the case, as the men were not even aware that these fish were being in any way regarded.

\section{The Composition of the Catch.}

The length frequencies of 2146 females and 2365 males, representing over three tons of fish, are shown in Table I above, each sex being subdivided, according to maturity. The measurements, arranged in $2 \mathrm{~cm}$. groups, are further displayed in diagrams (pages 78 and 79).

Care was taken to secure as fair a sample as possible of each catch dealt with. That this object was attained appears evident from the slight variations in the average sizes at the twenty-nine stations. For the males, of which the averages vary between the narrow limits of $40.4 \mathrm{~cm}$. and $41.9 \mathrm{~cm}$., a total average size of $40.7 \mathrm{~cm}$. is obtained; in the case of the females, as might be expected, a greater range in the average sizes occurs : $45.3 \mathrm{~cm} .-48.9 \mathrm{~cm}$., with one exception, $50.5 \mathrm{~cm}$. (in the smallest sample taken). The total average size of 2365 female fish is $46 \cdot 7 \mathrm{~cm}$.

The population consisted almost entirely of large mature fish, the total range of size being for males $24 \mathrm{~cm}$. to $57 \mathrm{~cm}$, and for females $24 \mathrm{~cm}$. to $73 \mathrm{~cm}$.

In Table II below the measurements for each sex are summarized in $5 \mathrm{~cm}$. groups, the percentage of males in each being also presented.

TABLE II.-Showing the measurements of Barents Sea plaice summarized in $5 \mathrm{~cm}$. groups, the percentage of males in each group being presented below :-

\begin{tabular}{|c|c|c|c|c|c|c|c|c|c|}
\hline $\mathrm{Cm}$. & $<30$ & $30-34$ & $35-39$ & $40-44$ & $45-49$ & $50-54$ & $55-59$ & $60+$ & Total. \\
\hline 8 & 12 & 79 & 634 & 1141 & 265 & 12 & 3 & - & 2146 \\
\hline$\cdot$ & 8 & 53 & 157 & 527 & 918 & 526 & 148 & 28 & 2365 \\
\hline Totals & 20 & 132 & 791 & 1668 & 1183 & 538 & 151 & 28 & 4511 \\
\hline of Males & 60 & 60 & 80 & 68 & 22 & 2 & 2 & 0 & 47 \\
\hline
\end{tabular}

The striking feature of this table is the great proportion of males in each group up to $40-44 \mathrm{~cm}$., and the subsequent rapid decrease.

The male plaice is generally recognised as being a constitutionally smaller fish than the female, and would not be expected to attain to 
the same length, but at the same time the rapid decrease after $44 \mathrm{~cm}$, and virtual disappearance after $49 \mathrm{~cm}$., is surprising.

In this recently spawned shoal the usual earlier maturity of the sex* would account for the great numbers of males in the smaller groups; for instance, in the $35-39 \mathrm{~cm}$. group 96 per cent of the males were mature, in contrast to only 11 per cent of the females. To only a small extent would this account for the high percentage of males being maintained in the next group, as only 8 per cent of the females now remain immature. We must look for some other explanation, which seems to me to lie in the probable infinitesimal annual growth which the males now undergo. The fishes of this sex are now some 10 or more centimetres above the size I have estimated for first maturity, after which stage in life considerable retardation of growth takes place $\dagger$ It is probable, therefore, that in these slow growing plaice (see p. 84) of the Barents Sea many year groups are comprised in this arbitrary $40-44 \mathrm{~cm}$. group.

It is probable, too, that the rapid diminution in numbers and final disappearance of males in the succeeding groups is accentuated by an earlier mortality of the sex here, as in the North Sea. $\neq_{+}^{+}$Looking at the curves of length frequencies it will be seen that the curve for the males does fall more rapidly from its mode or maximum height (at $41 \mathrm{~cm}$.) than does that for the females from its mode (at $47 \mathrm{~cm}$.).

The variation in the proportion of the sexes at individual stations and groups of stations, as possibly giving a clue to migrations, is dealt with later (p. 87).

The curves of length frequencies (Figs. 1 and 2) in the case of both sexes, display remarkable regularity, representing an absolutely intact stock of mature plaice, such as is to be found in no other region of the world at present fished. A series of annual observations, tracing the inevitable reduction of this stock by the influence of man, and a contemporary study of this fishery's statistics in their modern improved form, will throw interesting and valuable light on the changing aspects of a plaice fishery. Icelandic waters cannot now afford similar opportunities, for in the comparatively few years this region has been exploited for plaice a marked reduction of the original stock is observed by the fishermen to have occurred.

* Fulton. Twentieth Annual Report Fishery Board for Scotland, Part III, pp. 35460 (1902).

Wallace. Preliminary Investigations on the Age and Growth-Rate of Plaice. North Sea Investigation Committee, Report 2. Southern Area, 1902-3. Cd. 2670 (1905), pp. 218, etc.

+ Wallace. Report on the Age and Growth-Rate of Plaice in the Southern North Sea. North Sea Investigation Committee. Second Report (Southern Area), 1904-5, Part I, p. 33 , $\ddagger$ Wallace, Loc, cit., p. 34 . 
MALES.

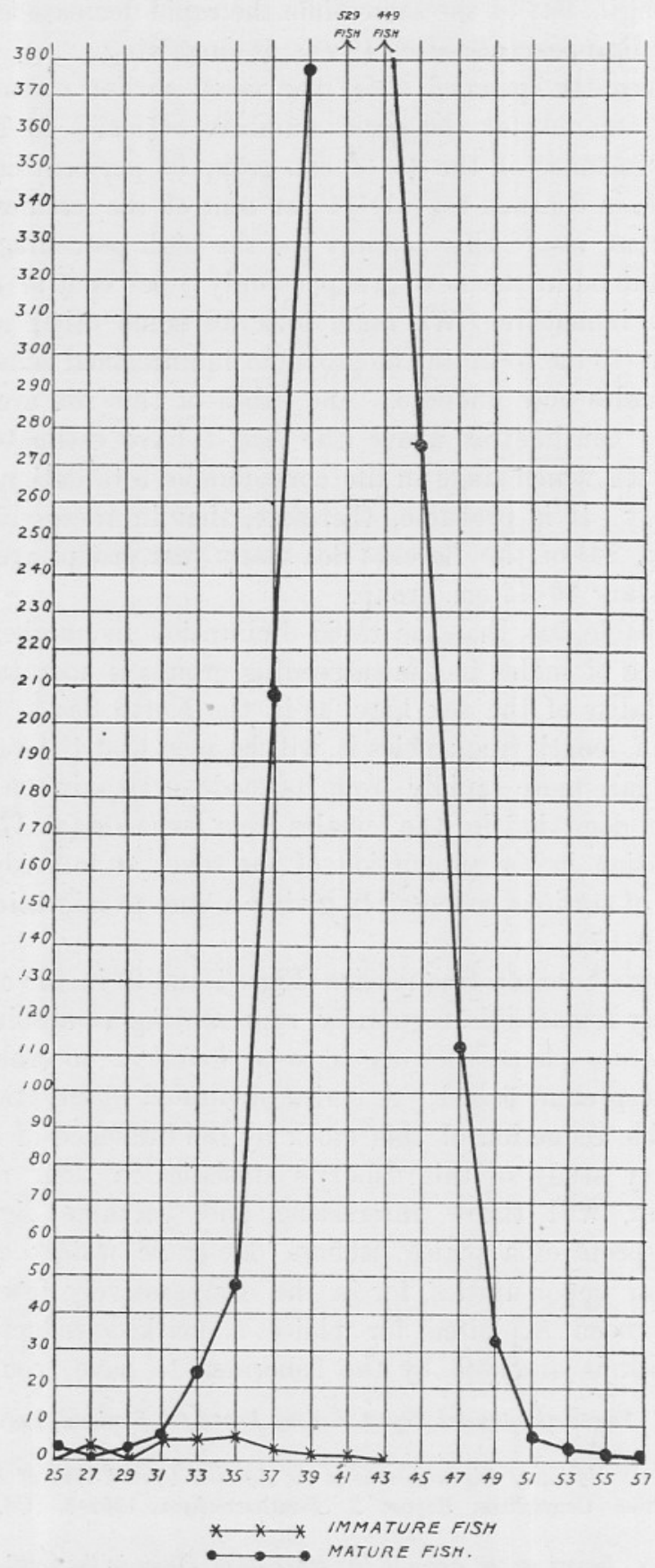

FIG. 1.-Showing the length frequencies in $2 \mathrm{~cm}$. groups of 2,101 male plaice. Barents Sea, August, 1907. 
FEMALES.

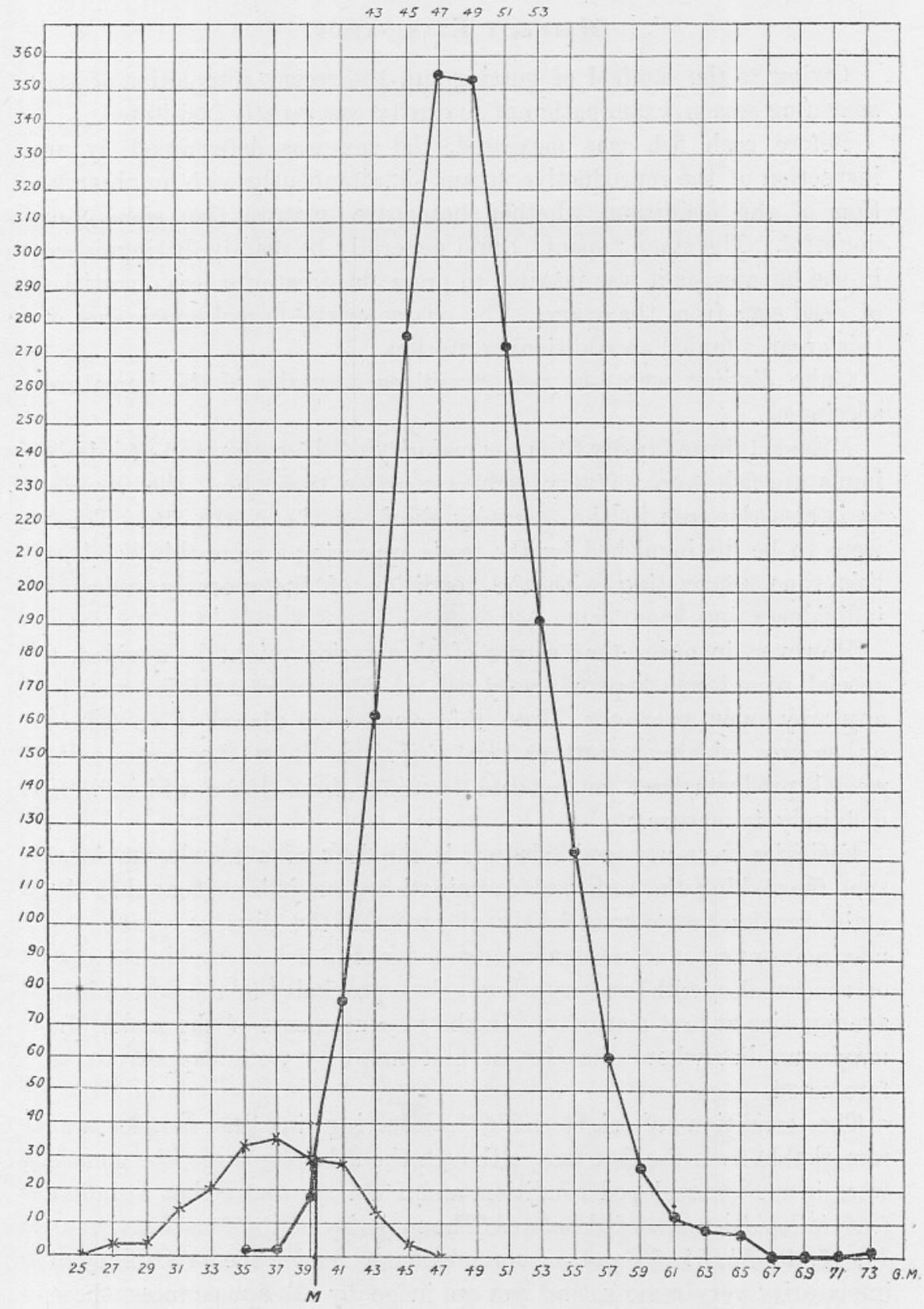

x- $\longrightarrow$ IMMATURE FISH.

VERTICAL LINE (M) AVERAGE SIZE

$\because$ MATURE FISH

AT FIRST MATURITY.

Frg. 2.-Showing the length frequencies in $2 \mathrm{~cm}$. groups of 2,125 female plaice. Barents Sea, August, 1907.

The length of the smallest mature male was $24^{\perp} \mathrm{cm}$, and of the smallest mature female, $35 \mathrm{~cm}$. The largest immature female was $45 \mathrm{~cm}$. The largest immature male was recorded as $41 \mathrm{~cm}$., but this record is rendered open to doubt by the curious condition of the eight males recorded above. The average size of the mature males is $40.9 \mathrm{~cm}$., and of the mature females, $48.3 \mathrm{~cm}$. 


\section{Maturity Examination.}

Owing to the method of gutting and the recent completion of the spawning season, examination of maturity was greatly facilitated.

Before each fish was measured, the sex was determined by an inspection of the reproductive organs simultaneously with an observation of the condition, whether immature, mature (i.e. spent), or doubtful. The stage "spent" could generally be readily distinguished in the females, as it was possible to press out greater or less quantities of dead eggs from the ovary. The characteristic flaccid appearance of this organ afforded an additional criterion.

Quite distinct were the taut, translucent ovaries of the immature specimens.

Milt still flowed freely from the majority of the males, and definitely immature fish were of very rare occurrence throughout the voyage, as is also the case in the spawning shoals of the North Sea. These were to be distinguished by the testis appearing a mere thin band, at this time contrasting with the condition of the recently spawned individuals.

- However, in order that errors of observation might be avoided, a special record was kept of every fish of which the condition was in any way open to doubt. Into this class were placed those fish of either sex which on further trial failed to show the presence of sexual products, and yet seemed to differ from those which were definitely immature.

Facilities were not available, nor is the deck of a trawler an ideal spot for making the minutest examinations, but it is evident that the main results are not seriously affected, as the size at which the maximum number of measurements of doubtful fish occurs, in the case of the females, will be seen to lie in close proximity to the determined average size at first maturity. In the measurements of the males, the maximum lies where the size at first maturity would appear to be forecasted.

The condition of eight males* occurring in the samples was remarkable from the fact that, although the fish were large, the gonads were in an undeveloped condition, and I am not aware that a similar feature has been recorded before. The majority of the lengths, viz. 40, $41,47,48,51,51,53$ and $57 \mathrm{~cm}$., obviously render the probability of immaturity very remote, and yet to judge by all appearances, these fish had certainly not been in a spawning condition in this year. In

* Two more occurred in the earliest samples, but I rejected them, thinking that the apparent absence of reproductive organs was due to accidental removal in gutting. 
one fish, $57 \mathrm{~cm}$., the testis, about $2 \mathrm{~mm}$. wide, was such as is found in the immature condition, but the measurement is the largest in the records for the sex. As regards the other seven fishes, no definite testis could be traced.

Whether this phenomenon was due to the lifelong sterility of the individuals, or to the fact that sterility had supervened on account of the great age to which they must have survived, is an interesting biological question which must for the present remain open.

Having made an extensive examination of spawning plaice in the southern parts of the North Sea in the spawning season (JanuaryFebruary) this year (1907), I received the distinct impression that the quantity of spermatic fluid and unextruded dead ova was far greater in the Barents Sea fish than in those of the southern region. It would be interesting if investigation should prove this to be actually the case.

No females actually spawning or about to spawn were found, and it will be seen from the summary of measurements that the number of immature fish of both sexes was very small, particularly in the case of the males.

It is interesting to find that the greatest number of immature oceurred in the haul across the shoalest part of the bank (26 fms.) at the end of the first day's fishing. The catch then consisted of eighteen baskets of plaice, of which four were measured. These contained 183 fish (73 males, 110 females). Of the males, 7, or $9 \frac{1}{2}$ per cent, were definitely immature; and 11 , or 15 per cent, recorded as doubtful. Of the females, 24 , or 22 per cent, were immature; and 5, or $4 \frac{1}{2}$ per cent, doubtful. Thus, of the fish in this sample, 18 males, or 25 per cent, and 29 females, or 26 per cent were possibly immature. Taking all the other stations, and classing the immature and doubtful fish together in the same way as "possibly immature," I find only about 3 per cent of the males, and 16 per cent of the females would fall into that category.

As a result of the international investigations in progress, we know that the same phenomenon, viz. an excess in the proportions of immature females compared with that of immature males, also obtains on the central grounds of the North Sea at a similar period.

The length of the smallest mature male was $24 \mathrm{~cm}$, and of the smallest mature female, $35 \mathrm{~cm}$. The largest immature female was $45 \mathrm{~cm}$. The largest immature male was recorded as $41 \mathrm{~cm}$., but this record is rendered open to doubt by the curious condition of the eight males recorded above. The average size of the mature males is $40.9 \mathrm{~cm}$, and of the mature females, $48 \cdot 3 \mathrm{~cm}$. 


\section{The Average Size at First Maturity.}

The average size at first maturity, that is to say, the size at which equal numbers of mature and immature fish occur, I find to be about $40 \mathrm{~cm}$. (see diagram, page 79), in the case of the females.

In regard to the males, owing to the virtual absence of immature individuals, this size cannot be determined. The indications, however, from the material available, point to this size being not far remote from $31 \mathrm{~cm}$.

These sizes correspond closely with those Dr. Wallace kindly informs me he has determined from 895 females and 561 males for the central grounds of the North Sea (Dogger, Flamborough Off Grounds, Clay Deep, etc.), viz., $40 \mathrm{~cm}$. for females and $31 \mathrm{~cm}$. for males. The correspondence is remarkable, and would hardly seem a mere coincidence. It is evident, however, that the plaice of the BarentsSea mature at a much later age (p. 85).

\section{AGE.}

The age investigation presents many difficulties. It is evident that the rate of growth is extremely slow, and this not only renders the distinction of year groups impossible by a study of the length frequencies (Petersen method), but it is also reflected in the otoliths, on which the annual rings are so narrow and crowded together that only in the case of the smallest fishes found has it been possible to estimate the age with a degree of certainty.

I made a small collection of otoliths on board the Roman, and although this material is quite insufficient for obtaining an estimate of the rate of growth, it can be seen that this is exceedingly slow, even during the years before maturity is attained.

A noticeable feature of these otoliths is the contrast of the comparative width of the white and dark rings, the latter being exceedingly narrow.

The physical conditions which apparently regulate the deposition of these respective rings have been studied in the case of plaice from the Baltic and North Seas.

Various investigators* have found that the white ring first shows itself in spring, when the temperature of the water commences to rise and the fish to feed. In late summer and into the autumn (the period

\footnotetext{
* Rerbisch. Ueber die Eizahl bei Pleuronectes platessa und die Altersbestimmung dieser Form aus den Otolithen. Wiss. Meeres. Abt., Kiel, N. F. Bd. 4, 1899.

MaIEr. Beiträge zur Altersbestimmung der Fische; Arb. d. wissen. Komm, f.d. Intern. Meeres. No. 5. Bd. viii., 1907.

Wallace. Loc, cit.
} 
of warmest water and most rapid growth in the North Sea) the dark ring is formed. In winter the growth of the otolith, as of the fish, ceases.

Immermann* has shown that these rings on the otoliths of the plaice are purely optical effects, explicable by the regular changes in the life conditions of the fish.

Avoiding technicalities, the reason for the occurrence of apparent white and dark rings is as follows: The whole otolith is composed of layers of chalk substance deposited regularly as the growth of the fish is in progress. Restrained growth, as when cold water conditions prevail, has the effect of crowding together these layers. As the temperature rises, and the growth rate of the fish increases, so must that of the otolith, and thus is effected a wider expansion of the layers of chalk substance. The optical effect of this is that the crowded rings, not permitting the passage of light, appear white, whilst the expanded translucent layers appear dark by contrast.

The reason for the narrowness of the dark ring, and the comparative great width of the white ring in the otolith of the Barents Sea plaice, is thus afforded. For the greater part of their annual growth-period these fish are subjected to very low temperature (at the time of my visit the bottom temperature was only two degrees Fahrenheit above the freezing point), so that for only a short period would rapid growth appear to take place, and it is not unlikely that this period coincides with the culmination of the Atlantic flood.

As has been pointed out before (p. 72), this expansion of Atlantic water is in progress in the month of August; in other words, biological spring has commenced. Correlated with this physical phenomenon the otoliths of the plaice show the commencement of a white ring at the edge. In the North Sea by this time, according to investigations (Wallace, Maier, etc.), the dark ring has commenced. Thus in the two regions of the ocean, many hundreds of miles apart, it can be seen on the otoliths of the plaice that biological spring in the one region coincides with midsummer in the other, as we know to be the case from hydrographic observations referred to above.

For suggestions and help in the investigation of the small collection of otoliths, I am greatly indebted to Dr. Wallace, who also kindly undertook an independent investigation of a number. Our two results were in close agreement, the chief discrepancies being in the case of otoliths on which certain of the rings appeared to split in a doubtful manner.

* Beiträge zur Altersbestimmung der Fische II. Die innere Struktur der Schollen Otolithen. Arb. d, wissen. Kom. f.d. Intern. Meeres. No. 6. Bd. vi., 1907. 
In Table III are shown the ages of certain individual fishes, reckoning that, as in the North Sea, one white ring is deposited annually, and that each fish had recently completed the number of years specified. In the case of the larger (older) fishes, the outer rings are so crowded together that accurate counting would seem impossible.

I have, however, included a few examples of these, estimating the age at not less than a certain number of years, as shown by the number of distinct white rings.

If fishes of either sex are not less than ten years old when $40 \mathrm{~cm}$. in length, to what age must a male of $57 \mathrm{~cm}$. or a female $73 \mathrm{~cm}$. in TABLE III.-Showing the age of certain individual plaice from the Barents Sea, August, 1907, estimated according to the number of white rings shown on the otoliths:-

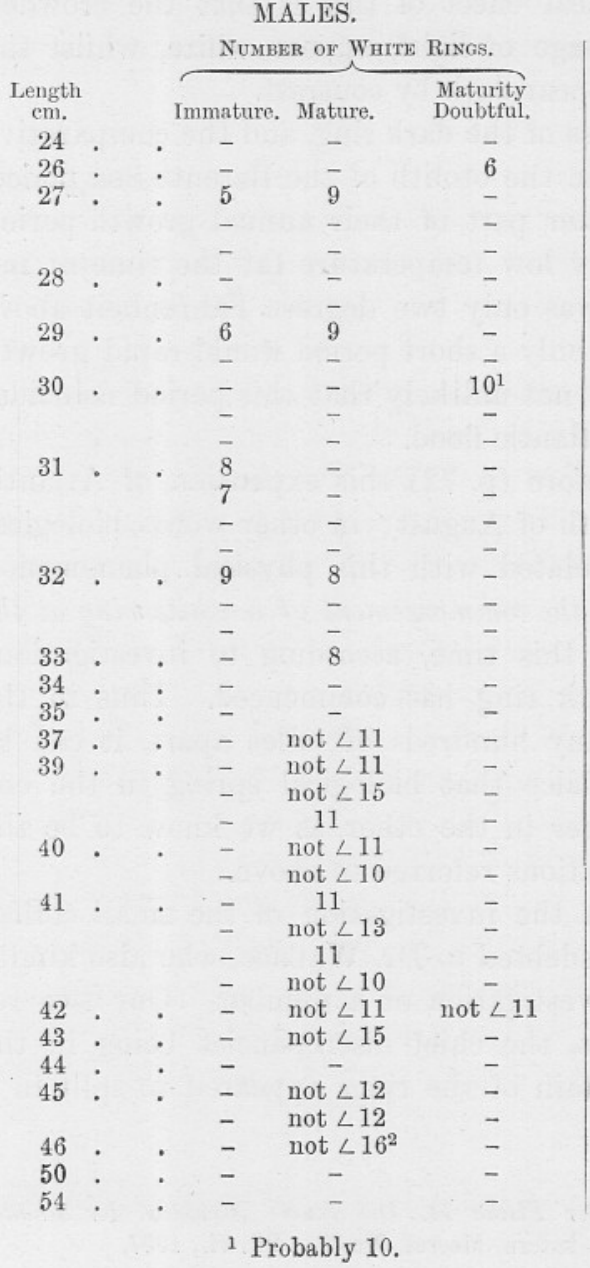

FEMALES.

\begin{tabular}{|c|c|}
\hline Number C & White Rings. \\
\hline Immature. & Mature. \\
\hline 6 & - \\
\hline $\bar{c}$ & - \\
\hline 6 & - \\
\hline 5 & - \\
\hline 6 & - \\
\hline 10 & - \\
\hline 6 & - \\
\hline 6 & - \\
\hline 6 & - \\
\hline 9 & - \\
\hline 9 & - \\
\hline 10 & - \\
\hline 7 & - \\
\hline 8 & - \\
\hline 8 & - \\
\hline 9 & - \\
\hline 9 & - \\
\hline 9 & - \\
\hline 9 & - \\
\hline 10 & - \\
\hline not $\angle 9$ & - \\
\hline 9 & - \\
\hline - & - \\
\hline - & - \\
\hline - & - \\
\hline - & $\overline{-}$ \\
\hline - & - \\
\hline not $\angle 12$ & not $\angle 12$ \\
\hline - & - \\
\hline$\overline{-}$ & $\overline{-}$ \\
\hline$\overline{-}$ & $\overline{-}$ \\
\hline$\overline{-}$ & - \\
\hline - & not $\angle 12$ \\
\hline$\overline{-}$ & $\overline{-}$ \\
\hline - & not $\angle 20$ \\
\hline- & not $\angle 21$ \\
\hline - & not $\angle 18$ \\
\hline
\end{tabular}


length have survived, considering that each year the growth becomes less and less !

Although the material in Table III cannot be regarded as satisfactory, it shows plainly how slow the rate of growth must be, and would seem indicative of the direction future plaice investigations should take in this inhospitable region.

In connection with the majority of these specimens (Table III), the possibility presents itself that they may be actually amongst the best grown fishes of their respective year groups. That plaice in the North Sea are larger for their age the further they are caught from the coastal grounds has been very clearly shown by Wallace in a recent paper (op. cit), so it seems possible, if not probable, that a similar state of things obtains in the off-shore grounds of the Barents Sea.

The youngest plaice of either sex amongst those examined had apparently already completed five years, but this would seem quite exceptional. In addition to the slow rate of growth, the evident late age at which maturity is attained is striking.

Amongst these few fish examined for age, no male less than eight years (32 cm.), and no female less than twelve years old $(41 \mathrm{~cm}$.) was found to be mature, though younger mature specimens must have occasionally been present in the catch (see Table I). In the North Sea few males are found to survive to eight years.

If the plaice in the Barents Sea have really to live through some eight or nine years before they attain the size at which they reproduce their species, the question occurs to us, "How long will the present stock, accumulated through many years, hold out in sufficient abundance to make this long, expensive voyage of three to four thousand miles down to the Arctic Ocean profitable to our trawlers?"

\section{Migrations.}

Speaking in a general way, the migrations of mature fish seem to be determined by the search for food, or to be in connection with the reproduction of the species. Currents, temperature, and such local factors as a general exodus from shoal to deeper water in stormy weather, are amongst other causes of fish movements, but all have more or less direct bearing on one of the main stimuli.

Although conclusions as to migrations in the Barents Sea would be impossible from the material collected on the voyage of the Roman, nevertheless every fact in my possession points to a general movement of this mature plaice population from deeper and here probably warmer water; after spawning has taken place, on to the banks to the eastward, apparently in search of food. 
That rich supplies of molluses were available, was evident from the frequent occurrence of living specimens in the trawl; the masses of crushed shells in the stomachs of the plaice and catfish; and, perhaps most important of all, the fine, plump condition of the plaice when first caught. This is a striking contrast to the condition met with a few years ago at Iceland, and reported of the earliest trawling times on the Dogger Bank.

How sensitive some fishes are to external conditions, when about to spawn, has been pointed out by Schmidt.* The same investigator has found more recently + that plaice marked on the north and east coasts of Iceland, migrate from their cold surroundings towards the warm Atlantic water, when preparing for reproduction.

As further contributing to our knowledge on this problem, I find that among the Lowestoft fishermen, whose fishing in January and February is almost entirely confined to the spawning plaice of the southermost North Sea, it is common knowledge that in a severe, cold winter, plaice always set in more abundantly, and remain longer, in the deep channels of this region, than is the case when the winter is mild. Hydrographic observations have shown that the water here is of Channel origin, and has a higher temperature at this period than any other part of the southern North Sea.

From the evidence I shall present below, it will be seen that the spawning plaice of the Barents Sea probably seek to the west the more congenial surroundings which their condition demands.

The Russian hydrographers ${ }_{+}^{+}$have pointed out how the ramifications of the North Cape current follow well-defined channels along the sea bottom towards the east, and we may perhaps justifiably surmise that the influence extends to the deep water west of the bank on which the present investigations were carried out.

At any rate, it is the experience of our fishermen that the plaice are found further to the west, and in denser shoals, when they first visit these grounds in June and July, than later in the season. I should estimate, from the condition of the fish taken by the Roman in August, that this year the spawning season terminated in July.

An analysis of the Roman's hauls of the first two days, relative to their respective positions and depths, reveals features which bear comparison with North Sea grounds at a similar period, viz., just after

* Johs Schmidt. " "Contributions to the Life History of the Eel," (Anguilla vulgaris. Turt.), Rapports et Proces-Verbaux, V, p. 234, et seq., 1906.

† Marking Experiments on Plaice and Cod in Icelandic Waters. Meddel. fra Komm. f. Havunders, Serie Fiskeri. Bind ii, No. 6, 1907.

$\ddagger$ Rapports et Procès-Verbaux, Vol. iii, 1905. Appendix A, pp. 3 and 4. 
spawning has taken place. This is in regard to the proportions of the sexes.

Recent investigations* have shown that a high percentage of males is characteristic of the catches in areas where plaice are spawning, or have reeently spawned. To gain additional knowledge on this point, I made, in the first days of February this year (1907), a voyage in the Lowestoft smack Rosebud, and measured all the plaice caught, 2631 fish, of these no fewer than 85 per cent being males. The spawning season had then about half expired.

TABLE IV.-Showing analysis of the total catch of plaice made by the Lowestoft sailing-trawler "Rosebud," January 31st to February 5th, 1907. Eastern Deep Water :-

\begin{tabular}{|c|c|c|c|c|c|c|c|c|c|c|}
\hline $\begin{array}{c}\mathrm{Cm} . \\
\delta \\
\$\end{array}$ & $\begin{array}{r}<20 \\
202 \\
1\end{array}$ & $\begin{array}{c}20-24 \\
648 \\
38\end{array}$ & $\begin{array}{c}25-29 \\
555 \\
148\end{array}$ & $\begin{array}{c}30-34 \\
505 \\
108\end{array}$ & $\begin{array}{c}35-39 \\
257 \\
48\end{array}$ & $\begin{array}{c}40-44 \\
50 \\
33\end{array}$ & $\begin{array}{c}45-49 \\
9 \\
23\end{array}$ & $\begin{array}{c}50-54 \\
- \\
4\end{array}$ & $\begin{array}{c}>55 \\
\overline{2}\end{array}$ & $\begin{array}{c}\text { Total. } \\
2226 \\
405\end{array}$ \\
\hline Totals & 203 & 686 & 703 & 613 & 305 & 83 & 32 & 4 & 2 & 2631 \\
\hline Percentage of Males & $99 \cdot 5$ & 95 & 79 & 82 & 84 & 60 & 28 & 0 & 0 & 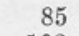 \\
\hline Spent Females & - & 7 & 18 & 26 & 24 & 18 & 7 & 2 & 1 & 103 \\
\hline Immature Females. & 1 & 26 & 115 & 64 & 6 & - & - & - & - & 212 \\
\hline
\end{tabular}

The early hauls of the Roman, referred to just above, were, roughly speaking, in a series-starting from the deep water to the west of the bank, extending over the same, and dropping again into deep water to the east of it.

Three hauls were made up the western slope at depths of 55,40 , and 38 fathoms. The complete catch of two of these hauls, and a greater part of the third, was measured, and the condition of the reproductive organs examined, the numbers showing that males greatly predominated here.

Out of the 294 fish comprising these samples, 179 , or 61 per cent, were males; the first haul, indeed, in 55 fathoms, resulted in a catch of 42 fish, of which 33 , or 79 per cent, were males.

Crossing the bank with water as shallow as 26 fathoms, measurements of two hauls were made, these samples amounting to 288 fish. The males now only numbered 123 , or 43 per cent.

In three hauls down the eastern slope, the water deepening to 49 fathoms and shoaling again to 40 , and eventually to 37 fathoms, an eighth, nearly half, and, on the third occasion, the whole of the catch was measured.

A complete reversal in the proportion of the sexes, as compared with the west side, had now taken place. Out of 319 fish dealt with, only 115 , or 36 per cent, were males.

After the last haul of this batch, the vessel steamed westward on to.

* Rapports et Procès-Verbaux. Vol, vii, 1907. Comm. B., p. 20.

NEW SERIES. - VOL. VIII. NO. 2. 
the body of the bank, and fish were eventually found in satisfactory quantities. The remaining 21 hauls, from which fish were measured, give 48 per cent of males.

It is evident that this unmistakeable change in the proportions of the sexes from west to east is not without significance, and when we consider that a great preponderance of males is characteristic of spawning areas in the North Sea during, and immediately after the spawning season, it would seem that we have a clue to where these plaice had spawned in the Barents Sea.

Evidence of a probable abundance of plaice some little time previously in the deep water to the west of the bank, was accidentally afforded in the following manner: When first approaching the intended fishing grounds, a trawler's fishing buoy was found anchored in 55 fathoms. No vessel was in sight, and it had been in the water some little time, evidently having been lost sight of in one of the frequent fogs. A trial haul of nearly two hours gave the result previously mentioned, viz., 42 plaice, 33 of which were males.

Now the experienced skippers who make this long voyage to the Arctic Ocean would only be likely to employ a buoy for one of two purposes-to mark either a rough ground, or a shoal of fish. In the latter case plaice would be the species, for in the present limited scope of the fishery this is the only species specially sought after in this region.

No rough ground was encountered in the haul taken, so the probability is that when the buoy was put down quantities of plaice were to be had in the vicinity. It was not until nearly two days later, after searching to the eastward and then returning to the body of the bank, that the Roman fell in with sufficient quantities of plaice to warrant the use of a fishing buoy.*

The rapidity with which an accumulation of plaice can under certain conditions disappear from a given spot, is a phenomenon well known amongst fishermen.

Thus we have evidence, indirect and admittedly not conclusive, yet from various aspects corroborative of a distinct eastward movement of these plaice subsequent to spawning. Conversely it would appear as if the westward migration, from this bank at least, into deeper water for the purpose of spawning, might be assumed.

* Since the above was written, information has been obtained on this point, which corroborates in each respect the surmises mentioned in the text. From distinguishing marks on the buoy, and through the courtesy of Captain Leighton, it has been possible to discover the Hull skipper who lost it. He states that it was actually on a bank with 52 fathoms, and was lost in a fog of two days' duration towards the end of June. At that time he was catching sixty baskets of plaice for a two hours' haul.

G. T. A., 27.12 .07 . 
Whither the eggs drift, where the larval forms reach the coastal shallows necessary for the development of young plaice, the life history of these, and where they spend the long years before they reach the outer grounds as mature fish, all afford highly interesting subjects for future investigation.

The pioneering trawlers have found that the plaice are smaller near Cape Kanin, as would be expected, but neither here nor in the entrance to the White Sea, has any great quantity of small fish been found. A study of the Admiralty chart reveals the fact that west of Long. $45^{\circ} \mathrm{E}$., the water deepens from the coast comparatively rapidly; indeed, no extensive tracts of shallow water overlying a fine sandy bottom such as characterize the small plaice nurseries in the North Sea, are indicated until Long. $53^{\circ} \mathrm{E}$. is passed.

Thereafter to the eastward a long, broad area of fine sandy ground extends across the wide mouth of the Pechora River. It is perhaps significant that the glass balls which Norwegian fishermen employ in connection with their fishing gear, have been found at the mouth of this river.* This reminds us of the drift of derelict fish trunks from our fishing fleets in the North Sea, which with other flotsam, find their way on to the beaches of Holland, Germany, and Denmark, as do also the early developing stages of the plaice.

That this class of evidence is not without significance is shown by the results of later scientific experiments with drift bottles, $\uparrow$ by which the trend of the surface currents in the North Sea has been determined.

How the Investigation of the Platce Fishery in the Barents Sea may throw Light upon the Condition of that Fishert IN the NoRth SEA.

It is now desirable to see if from this mass of material from a virgin fishing ground, we can gain any light upon the condition of the plaice fishery in any comparable area of the North Sea.

It must at the outset be recognized that many conditions of life must differ vastly, and yet we have aspects from which this fishing bank in the Barents Sea and the central grounds of the North Sea are comparable as regards the plaice populations at present found on each.

We have the sea bottom in both cases deepening from the coast, whence we may take it the small plaice originate. Far out to sea the

* Nansen. Oceanography of the North Polar Basin, Part II, p. 263.

† Fulton. "The Currents of the North Sea and their Relation to Fisheries"; Fifteenth Annual Report Fishery Board for Scotland, Part III, 1897.

Garstang. "Report on the Surface Drift of the English Channel and Neighbouring Seas during 1897," Journ. M, B, A, , Vol, v. 
bottom rises, forming a bank or banks, rich in the food of plaice: in one case the Dogger Bank, in the other, this uncharted bank discovered by the fishermen from Hull, and on which my investigations were made.

Further seawards in both areas, depths are eventually attained which cease to interest the plaice. In this regard, the Barents Sea is more comparable with the North Sea than is Iceland, where the plaice are restricted by the configuration of the sea bottom to a comparatively narrow coastal zone, throughout their lives. Biologically,

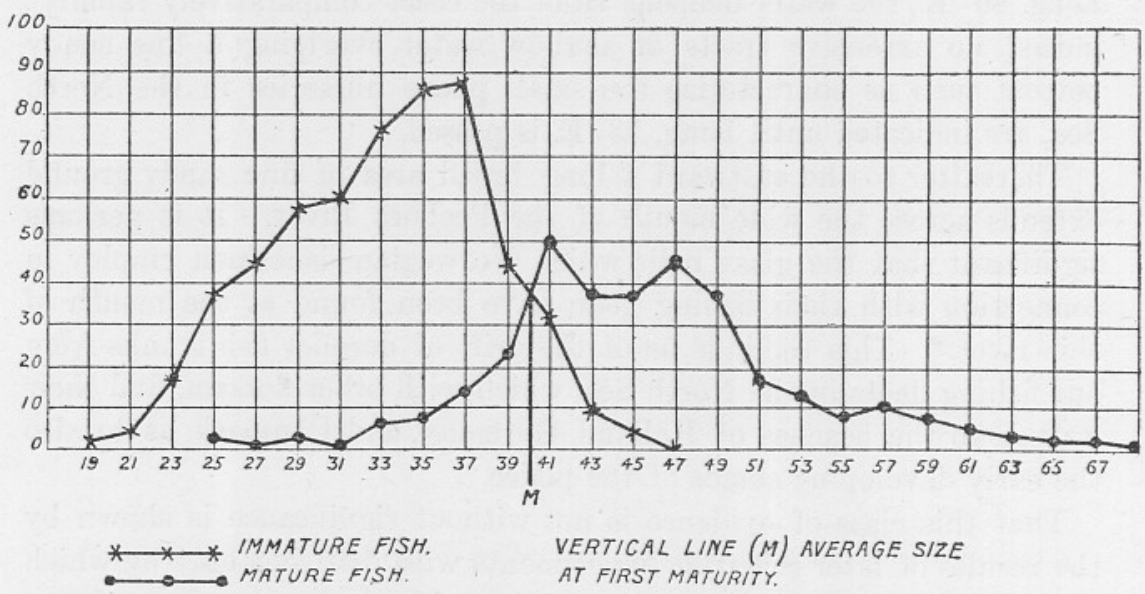

FIG. 3.-Showing the length frequencies of 895 female plaice from the central grounds of the North Sea (Dogger Bank, Clay Deep, etc.).

The ordinates at $19,21,23$, etc., represent the frequencies in $2 \mathrm{~cm}$. size groups 18-19, 20-21, 22-23 cm. ete.

for both regions, we have this important standpoint from which a comparison can be obtained.

The average size of the females at first maturity was found to be $40 \mathrm{~cm}$. (approximately), the same as in the central part of the North Sea.*

Moreover, it is remarkable that out of 2365 and 895 fish from the Barents Sea and the central part of the North Sea respectively, the size of the largest fishes definitely determined as immature should be $45 \mathrm{~cm}$. (Cf. Wallace, Fig. 3).

In order to compare the populations from this standpoint, I have constructed curves of the actual length frequencies of mature and immature female fishes in the two regions (Figs. 2 and 3, pp. 79, 90).

For the rich material from which that for the central North Sea is

* Fulton. 20th, 22nd, and 24th Ann. Report. Fishery Board for Scotland.

HoLt. Journ. M. B. A., Vol. ii.

KYLE. 18th Ann. Report. Fishery Board for Scotland,

WALLACE, op. cit. 
constructed, I am indebted to Dr. Wallace, who has made the determination of the maturity of 895 female fish on the fishing grounds of the Dogger Bank, Clay Deep, and off Flamborough Head.

In this curve for the central North Sea we find that the immature females, commencing at $18-19 \mathrm{~cm}$., attain their greatest frequency at $36-37 \mathrm{~cm}$., and ultimately disappear after $45 \mathrm{~cm}$. The smallest mature female occurs at $25 \mathrm{~cm}$, with the actual greatest frequency at 40-41 cm. This curve, however, representing the mature fish, rises again at $46-47 \mathrm{~cm}$., so that it seems that its real mode lies between these groups. The largest fish in this collection was $66 \mathrm{~cm}$. long.

In the curve for the Barents Sea (Fig. 2), the smallest immature female was at $24 \mathrm{~cm}$, and then, as in the central part of the North Sea, the greatest frequency occurs at $36-37 \mathrm{~cm}$., and the largest immature specimen at $45 \mathrm{~cm}$. The smallest mature female was found to be $35 \mathrm{~cm}$. in length, and the greatest frequency occurs at $46-47 \mathrm{~cm}$. (thus coinciding with the second mode in the curve for the mature North Sea females, Fig. 3). The largest specimen had a length of $73 \mathrm{~cm}$.

The size at which the numbers of immature and mature are equal (the average size at first maturity), represented by the line $\mathbf{M}$, is for each curve in the vicinity of $40 \mathrm{~cm}$.

Thus in the Barents Sea with its intact stock of plaice, the mode of the length frequency curve (Fig. 2), viz., $46-47 \mathrm{~cm}$, is some $7 \mathrm{~cm}$. higher than the average size at first maturity, viz., $39-40 \mathrm{~cm}$. On the other hand, in the diagram (Fig. 3) representing the stock in the central parts of the North Sea, we should naturally not expect to find any such great accumulation of mature fish; but it is somewhat alarming to find that the mode here $(36-37 \mathrm{~cm}$.) fails by $3 \mathrm{~cm}$. to reach the average size at first maturity $(39-40 \mathrm{~cm}$.). That is to say, some factor is at work which keeps down the plaice population to such an extent that the greater proportion are not, at the present time, once permitted to reproduce their lind. If we compare this with Dr. Petersen's previous discussion of these points in his paper, "What is over-fishing?" (Journ. M. B. A., Vol. vi., 1903, pp. 587-94), it would appear as though the chief theoretical effects of over-fishing in the North Sea, suggested in that paper, were now being substantiated.*

It may be that this enormous contrast is partly due to the fact that

* Kyle (Journ. M, B. A., Vol. vi, p. 496) suggests that one effect of fishing a plaice population is to reduce the average size at first maturity. The Barents Sea will afford the opportunity of testing this; meanwhile, if we were to accept the suggestion that such a reduction has taken place to the extent of, say, $5 \mathrm{~cm}$. in home waters, the deterioration of the stock would be still more evident, and even a greater proportion of North Sea plaice than my curves tend to show would be prevented from attaining maturity. 
the fish dealt with in the Barents Sea were possibly selected naturally by the function of spawning, and that immature fish.had not migrated so far seawards to an appreciable extent. I think this is in part probable, and that in the North Sea a similar state of affairs may have once obtained, but has now undergone the following change :-

Formerly the plaice population was dense on suitable areas, from the nursery grounds out to such a central ground as the Dogger Bank, and the food supply was everywhere restricted. The early influence of man's fishing was to reduce the numbers of the largest fish at proportionally the greatest rate, and thus reduce the density of the population on the central grounds.

Better feeding conditions would now be afforded on the central grounds, and to these the younger plaice would tend to move more and more, as the reduction in the numbers of the older individuals became more appreciable. At the present time there seems no doubt that density of population is restricted to the nursery grounds, so it is to the advantage of the individuals to radiate rapidly to the more favourable surroundings offshore. Thus it may be that the larger of the immature plaice extend further seawards than was formerly the case, i.e., emigrate at an earlier age, in consequence of the reduced competition within the species on the offshore grounds.

At any rate, whether it was the case or not in former times, there is now to be found everywhere, and at all times in the North Sea, a proportion of immature fish many times greater than I found this year in the Barents Sea. Even amongst the spawning shoals in the North Sea it is quite usual to find as many immature female fish as mature.

On the other hand, it may possibly be that we have on this bank in the Barents Sea an accumulated stock of plaice such as the Norwegian investigators* have shown to have existed in suitable areas on their coast, on a much smaller scale. When these spots were first fished, quantities of large plaice were to be obtained. After a few years, however, the population appeared to have been almost entirely fished out, the explanation being that the currents, setting out of the fiords, carry the majority of the floating eggs and young fish to water in which they cannot develop. The capture of the stock is thus out of all proportion to its renewal by natural means, and the decay of the fishery in these particular spots is inevitable.

From this it would seem to be of the greatest importance for the future welfare of the plaice fishery in the Barents Sea, that steps should be taken to ascertain definitely whether extensive nursery

\footnotetext{
* Report on Norwegian Fishery and Marine Investigations. Vol. i., 1900, pp. 138-52.
} 
grounds actually exist, from which the stock of the outer grounds may be renewed.

If the majority of the eggs and larvæ are carried by currents to regions in which they must naturally perish, as Hjort and Dahl (loc. cit.) have shown to be the case on parts of the Norwegian coast, it is evident that the fishery can only flourish so long as the present stock, accumulated through a great number of years, continues to be sufficiently abundant to pay for its capture.

It is not difficult to imagine that there may have been a period when the central grounds of the North Sea were inhabited by a plaice population, of which at least the majority of the individuals were mature; and, had we a curve of measurements of that period, the mode would conceivably have exceeded the average size at which the fish were first mature, by an amount as great as may now be found in the virgin waters of Northern Europe.

One of the earliest effects of fishing on any ground is to reduce the number of the large fish, and consequently lower the average size; that is to say, representing this effect on a diagram to compare with Figs. 2 and 3 , the mode will recede to the left, and approach the size at which the species becomes mature.

If it is allowed that an accumulation of mature plaice once preponderated in the central North Sea, it will be obvious that the retrogression of this modal size to its present position $(36-37 \mathrm{~cm}$.) below the average size at first maturity $(39-40 \mathrm{~cm}$.) must have been effected gradually by the influence of man, for no serious natural enemy of large plaice in the North Sea is recognised, whilst the intensity of fishing is known to be very great.

Hence it is conceivable that if intense fishing continues, the modal size of the plaice will imperceptibly recede to even lower limits, and a period must arrive, if it is not already with us, when the supply of eggs, and consequently young fish, seriously suffers.

\section{Summary.}

In this preliminary investigation of the plaice on a bank in the Barents Sea the following were among the chief features noted:-

1. The population consisted almost entirely of mature fish, thus presenting a marked contrast to the conditions prevailing at the present day in the central parts of the North Sea (Dogger Bank, etc.).

2. The "average size at first maturity" for the females appears to be approximately the same $(39-40 \mathrm{~cm}$.) in the Barents Sea as in the central parts of the North Sea: but, whereas in the Barents Sea the 
predominant size is several centimetres above, in the central parts of the North Sea it is several centimetres below that standard.

In other words, whereas on the virgin grounds of the Barents Sea the female plaice live to spawn many times, in the southern muchfished region the majority at the present time do not live to spawn once.

3 . The number of rings on the otoliths indicate a remarkably slow rate of growth and great age attained in this region as compared with the North Sea. It also appears from these investigations that "biological spring," and also the spawning season, is some three to five months later than in the North Sea, viz. in mid summer.

4. On this voyage the differences in the proportions of the sexes at different sizes was striking. Up to a certain size $(40-44 \mathrm{~cm}$.) males were in great excess; after this, rapid diminution in their numbers took place.

In the North Sea the same two features have been found to occur, and are connected respectively with the spawning habits of the species and with earlier mortality of the male fish and its slower rate of growth.

5. Various evidence points to the existence of a spawning ground somewhat to the westward of the bank where the fishing took place.

\section{OTHER SPECIES.}

The few other species which occurred during this voyage were as follows :-

Dab (Pleuronectes limanda).

Long Rough Dab (Hippoglossoides platessoides).

Halibut (Hippoglossus vulgaris).

Cod (Gadus morrhua).

Haddock (Gadus aeglefinus).

Catfish (Anarrichas (minor ?)).

Greenland Shark (Laemargus microcephalus).

Starry Ray (Raia radiata).

Lump-fish (Cyclopterus lumpus).

and Cyclopterus (Eumicrotremus) spinosus, Müll.

A Cottoid (Gymnacanthus tricuspis).

\section{Dab (Pleuronectes limanda).}

This species was of very rare occurrence in the area visited. Only four were observed, all being large; two of these measured 35 and $36 \mathrm{~cm}$. respectively. On an otolith from the latter fish seventeen white rings appear very clearly, tending to show that the rate of growth of this species, like that of the plaice, is exceeding slow in these waters. 


\section{Long Rough Dab (Hippoglossoides platessoides).}

This fish occurred in small numbers every haul. It appears to attain a much larger size here than in the North Sea, where the majority recorded by Fulton* are below $15 \mathrm{~cm}$., and only an occasional specimen over $25 \mathrm{~cm}$. A sample of 42 measured from one haul on the Roman ranged from 19-39 cm., the majority being between 25 and $29 \mathrm{~cm}$. Slightly larger and smaller fish probably occurred, but no very small specimens were observed. The species is not brought to market at present.

\section{Halibut (Hippoglossus vulgaris).}

Four only were caught. Two measured 66 and $78 \mathrm{~cm}$., the other two being a little larger and a little smaller than the lengths recorded. Examination of the otoliths of the fish $78 \mathrm{~cm}$., a male, shows it to be apparently either seven or eight years old.

The species has but rarely been met with in the region, though from the Russian records it would appear to be more abundant further west. The specimens found on this occasion were probably all immature.

\section{Cod (Gadus morrhua).}

Small individuals occurred in practically every haul, and on one or two occasions in abundance.

A sample basket (52 fish) out of about three was measured from a haul on the second day, and the whole catch (51 fish) eight days later. The features presented by the tabulation of these measurements, if not accidental, are interesting.

In the first sample the sizes range $30-49 \mathrm{~cm}$., with an exceptional fish $58 \mathrm{~cm}$., the maximum number of measurements grouping about $40-42 \mathrm{~cm}$.

The fish in the second lot had a range of size, $27-52 \mathrm{~cm}$., with a very exceptional specimen $82 \mathrm{~cm}$. The maximum of length frequencies occurs some $8 \mathrm{~cm}$. lower, $32-34 \mathrm{~cm}$., with a smaller maximum at $42 \mathrm{~cm}$.

The possibility presents itself that two year groups are chiefly represented, the younger sparsely at the former station, and predominating at the latter, which would be further east than the early haul.

The above-mentioned specimen $(82 \mathrm{~cm}$.) was much the largest noted, other exceptionally large fish measuring 60, 69, 70, $77 \mathrm{~cm}$., but never

\footnotetext{
" "Rate of Growth of Sea Fishes." Twentieth Annual Report, S. F. B.
} 
more than one or two such large fish could be found in any haul. Mature cod at this time were thus practically absent from the area visited. Small codling have been found in quantities by the trawlers towards Bear Island.

\section{Haddock (Gadus aeglefinus).}

In the first haul (55 fms.) thirty fish were caught ranging from $24-34 \mathrm{~cm}$.

Throughout the remainder of the voyage such small specimens were only rarely to be found. Very large fish up to $81 \mathrm{~cm}$. were caught in quantities varying from one or two fish in a haul up to, on one occasion, 143 fish. These fish had evidently spawned some time previously.

An increase in the catch was noticeable in the few hours the sun was below the horizon.

In $1906 *$ Dr. Hjort procured some large haddock from the catch of a Hull trawler which had been fishing in this region. His specimens were from $55-80 \mathrm{~cm}$. in length, and their ages determined by investigation of the scales ranged between nine and fourteen years.

\section{Catfish (Anarrichas (minor?)).}

I have records of this fish occurring regularly throughout the voyage in number from one to about a score a haul. With one exception $(49 \mathrm{~cm}$.) all the specimens were very large.

Two catches, 10 and 11 fish respectively, were measured, the range of size being $88-120$ and $102-125 \mathrm{~cm}$. These ranges and the quantity were typical of most of the hauls in the region at this time.

On various occasions stomachs of seven fish were examined. Crustacea (Hyas) and Mollusca appeared to be the staple food, though in one stomach I found three codling.

\section{Greenland Shark (Laemargus microcephalus).}

Called by the fishermen "oakettle."

Fourteen were recorded, but one or two more occurred. Of these fourteen, eight were measured, viz., $14 \mathrm{ft}$. (427 cm.), $12 \mathrm{ft}$. (366 cm.), $11 \mathrm{ft} .4$ ins. (346 cm.), $10 \mathrm{ft.} 6$ ins. ( $320 \mathrm{~cm}$.), two specimens $7 \mathrm{ft}$. $(213 \mathrm{~cm}$.), $6 \mathrm{ft} .10$ ins. $(208 \mathrm{~cm}$.), and $5 \mathrm{ft.} 6$ in. $(168 \mathrm{~cm}$.). No very small specimens were found.

Difficulty was experienced in examining the stomach contents of

* Johan HJort. "Nogle Resultater af den Internationale Havforskning," Saertryk af . Aarsberetning vedk. Norges fiskerier, 1907. 
these cumbersome creatures. Steam power was necessary to remove them from the remainder of the trawl contents, so that this and hoisting over the ship's side was made one operation. Before cutting the monsters adrift a lateral incision was made through which the liver was extracted.

To have opened the stomach as the fish lay upon the heap would not have improved the remainder of the catch. In two instances, however, I was able to examine the stomach contents.

In the first instance the food consisted of three codlings, about $40 \mathrm{~cm}$., and a plaice of the same length. On the second occasion I found in a fish $6 \mathrm{ft} .10 \mathrm{ins}$. (208 cm.) in length two round fish (one probably a codling, about $60 \mathrm{~cm}$. in length), one long rough dab, and a piece some twelve inches long from the mid-lateral region of one of the salmon species (Salmo salar?) evidently a large fish.

Quantities of plaice could be observed at times pouring from the mouth of these sharks when suspended by the tail and lowered over the ship's side. That their depredations amongst the plaice are great, I feel convinced. I do not think the missing and damaged tails, so frequent as to be commonly noted by the fishermen, can be otherwise accounted for.

I have observed in the North Sea that when the dogfish (Acanthias vulgaris) feeds on small plaice, these are devoured from the tail first, in contrast to round fishes, such as herring, which are taken head first.

In my samples, the significant number of 113 fish, or nearly $2 \frac{1}{2}$ per cent of the total, I found with tails more or less damaged, and subsequently healed; in some instances the whole tail had disappeared. The possibility of this phenomenon being the result of disease, such as is sometimes found to be destroying the tails and fins of fresh-water fish, would seem excluded, as the damaged extremities were clean and healthy. In the only exception the extremities of the tail rays were raw and bleeding.

All these facts, in conjunction with the concave shape of the majority of the assumed bites, seemed to me to point to the successful escape of the individual plaice from the jaws of a Greenland shark, though, as previously suggested, the possibility of depredations by seals must not be overlooked.

\section{Starry Ray (Raia radiata).}

This was the only ray species which occurred, and only occasional, full grown specimens were to be seen. Two female fish in one haul measured 35 and $37 \mathrm{~cm}$. between the extremities of the pectoral fins. In the stomach of each of these was found two large specimens of the Arctic shrimp (Sclerocrangon boreas), identified by Mr. R. A. Todd. 


\section{Lump-fish (Cyclopterus lumpus).}

One medium-sized specimen was found.

Lump-fish (Cyclopterus (Eumicrotremus) spinosus, Müll).

Two or three individuals of this lump-fish occurred during the first day or two of the voyage, but it was not observed afterwards.

\section{A Cottoid (Gymnacanthus tricuspis, Reinh.)}

This was represented on the voyage of the Roman by one specimen. For the identification of this and the preceding species, my thanks are due to Mr. L. W. Byrne.

\section{EXPLANATION OF PLATE IV.}

Photograph of a three hours' catch of plaice in the Barents Sea (about 40 baskets), s.t. Roman, H 948, Aug., 1907.

General Chart of Barents Sea. 


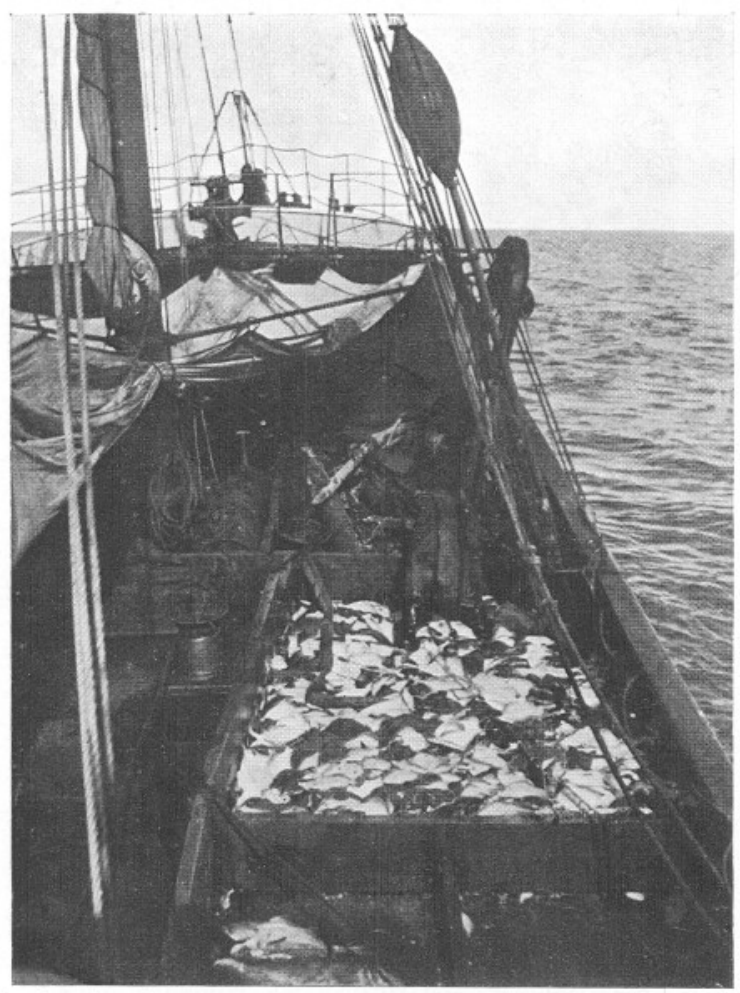

Photograph of a three hours' catch of plaice in the Barents Sea (about 40 baskets), s.t. Roman, H 948, Aug., 1907.

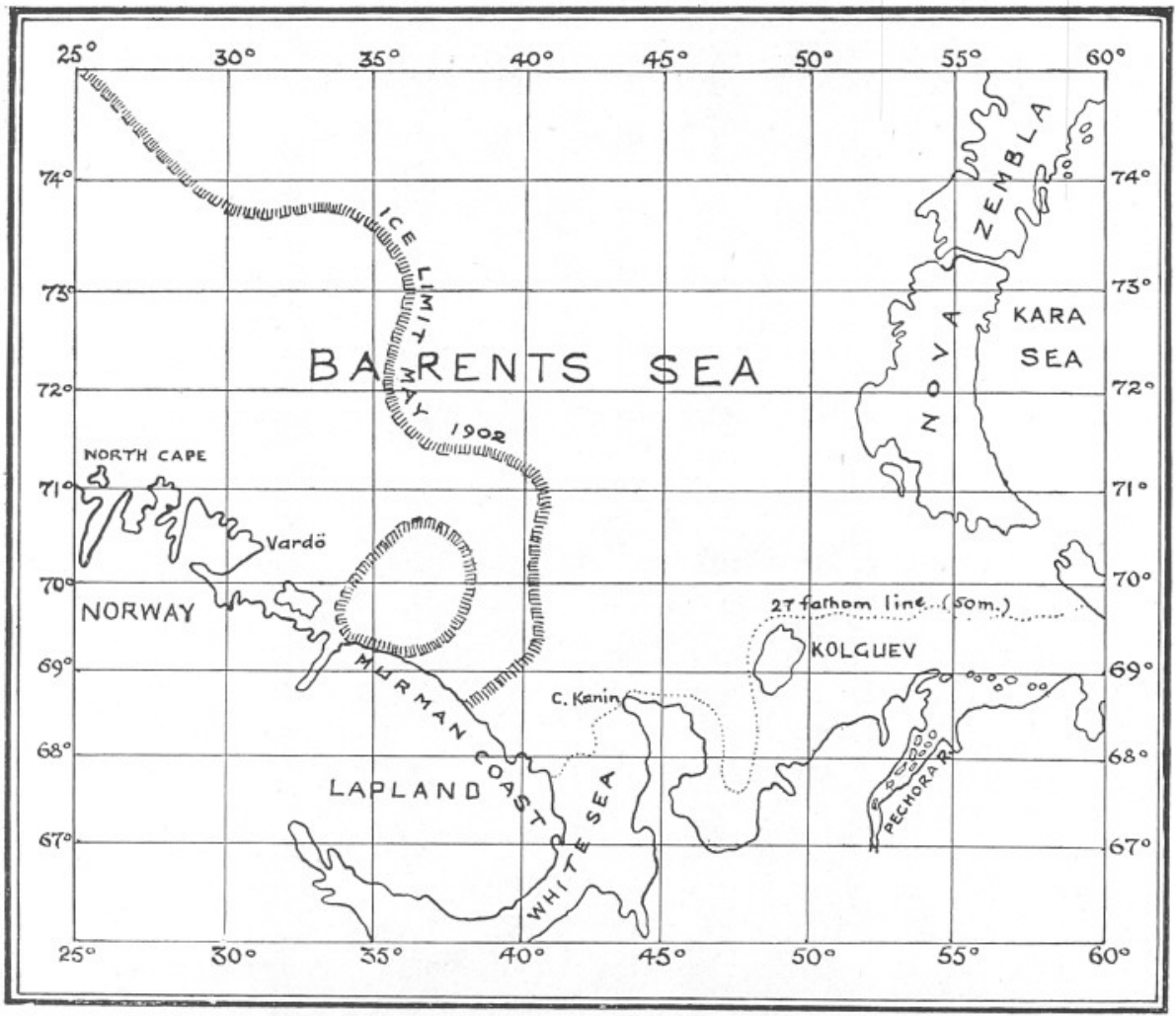

General Chart of Barents Sea. 